\title{
M. Haspelmath
}

Max-Planck-Institut für Menschheitsgeschichte, Jena, 07745, Germany;

Universität Leipzig,

Leipzig, 04109, Germany

\section{Ergativity and depth of analysis}

In this paper, I argue that "depth of analysis" does not deserve the prestige that it is sometimes given in general linguistics. While language description should certainly be as detailed as possible, general linguistics must rely on worldwide comparison of languages, and this cannot be based on language-particular analyses. Rigorous quantitative comparison requires uniform measurement, and this implies abstracting away from many language-particular peculiarities. I will illustrate this on the basis of ergative patterns, starting out from I.A. Mel'čuk's (1981) proposal for Lezgian. This proposal was not successful, but why not? And why is Baker's (2015) theory of dependent case likewise unsuccessful? By contrast, quantitative worldwide research has found striking similarities of ergative coding patterns, which can be explained by the efficiency theory of asymmetric coding. I will argue that this success is due to a more cautious approach to understanding Human Language, which does not rely on the Mendeleyevian vision for grammar (that all grammars are made from the same innate building blocks).

Key words: syntactic analysis, ergative construction, language typology, grammar blueprint

Acknowledgements. I am very grateful to Anton Zimmerling and Ekaterina Lyutikova for inviting me to present a talk at their Moscow conference "Typology of Morphosyntactic Parameters".

In addition, the support of the European Research Council (ERC Advanced Grant 670985, Grammatical Universals) is gratefully acknowledged.

FOR CITATION: Haspelmath M. Ergativity and depth of analysis. Rhema. 2019. No. 4. Pp. 108-130. DOI: 10.31862/2500-2953-2019-4-108-130

(C) Haspelmath M., 2019

Контент доступен по лицензии Creative Commons Attribution 4.0 International License

The content is licensed under a Creative Commons Attribution 4.0 International License 


\section{М. Хаспельмат}

Институт истории человечества общества Макса Планка, 07745 г. Йена, Германия;

Лейпцигский университет, 04109 г. Лейпциг, Германия

\section{Эргативность и глубина анализа}

В статье я доказываю, что «глубина анализа» не заслуживает того авторитета, который она часто имеет в лингвистике. Хотя описание языка должно быть насколько это возможно детальным, общая лингвистика должна опираться на межъязыковое сравнение, а последнее не может базироваться на анализе конкретных языков. Тщательное количественное сравнение требует единообразной общей меры, что означает необходимость абстрагироваться от многих частноязыковых особенностей. Этот тезис я проиллюстрирую при помощи анализа эргативной конструкции предложения, начиная от анализа эргативности в лезгинском языке И.А. Мельчука (1981). Этот подход не увенчался успехом; в равной степени неудачной оказалась и теория зависимого падежа М. Бейкера (2015). Напротив, широкомасштабные квантитативные исследования обнаружили удивительное единообразие эргативных кодирующих техник, которое может быть объяснено теорией эффективности асимметричного кодирования. Я продемонстрирую, что в основе этого успеха лежит более осмотрительный и сдержанный подход к пониманию человеческого языка, который расходится с «менделеевским представлением» о грамматике, предполагающем, что все грамматики строятся из одних и тех же врожденных блоков.

Ключевые слова: синтаксический анализ, эргативная конструкция, лингвистическая типология, модели грамматики

Благодарности. Я признателен Антону Циммерлингу и Екатерине Лютиковой за приглашение выступить на проводимой в Москве конференции "Типология синтаксических параметров".

Кроме того, я благодарен за поддержку Европейского исследовательского совета (ERC Advanced Grant 670985, Grammatical Universals).

ДЛя ЦИТИРОВАНИЯ: Хаспельмат М. Эргативность и глубина анализа // Рема. Rhema. 2019. № 4. C. 108-130. DOI: 10.31862/2500-2953-2019-4-108-130 


\section{Introduction}

In this short paper, I question the widespread idea that we need "deep" and "detailed" language-particular analyses as a prerequisite for a better understanding of general grammar, and I use the example of ergative constructions to illustrate this point.

Instead of deep and detailed analyses, I argue that what we need primarily is hypotheses that are objectively testable not only in principle, but also in practice. There is nothing wrong with detailed analyses, of course, and eventually we want them for all languages, but it is often simply presupposed that deep analyses contribute to a better understanding of Human Language (= to general linguistics, or g-linguistics). However, while such analyses of a particular language obviously contribute to a better knowledge (and perhaps also a better understanding) of this particular language (i.e. of its p-linguistics), general theories of Human Language must be based on general phenomena that do not depend on historical accidents, i.e. on grammatical universals.

Ergative constructions provide a good example in the present context, because the Moscow-trained linguist Igor A. Mel'čuk developed an interesting account of ergativity in Lezgian which inspired me early in my career, and the Moscow-trained linguist Maria Polinky has a recent book about ergative constructions [Polinsky, 2016]. ${ }^{1}$ But I will also discuss Mark Baker's recent book Case (2015), because it represents a particularly influential line of thought in comparative grammar.

I will end up arguing that uniformity of "measurement" is crucial for objective hypothesis-testing, but I recognize that there is a serious alternative: What I call "building block uniformity", based on the idea that there is a substantial set of innate building blocks (features, categories, architectures) which are part of a universal grammar blueprint and form the basis of all language systems. This view is akin to the idea of a few dozen chemical elements that all kinds of stuff are made out of, so I call it the "Mendeleyevian Vision" (cf. [Baker, 2001]). This view seems to have been adopted implicitly by many researchers, but once its implications are made explicit, it turns out to be quite unlikely (though not impossible) to be correct.

${ }^{1}$ I mention this because the current paper is based on a presentation I gave in Moscow at the "Typology of Morphosyntactic Parameters" conference (October 2019), where Maria Polinsky was the other invited speaker. It is not otherwise relevant for the points I am making here. 


\section{The Lezgian ergative construction}

Igor A. Mel'čuk (*1932) was a visiting professor at the University of Vienna in 1983, when I was a first-year student there. There I learned about Mel'čuk $(1981 ; 1988)$, a paper that offers an intriguing theory of Lezgian clause structure: Mel'čuk claimed that Lezgian has no transitive ergative construction, but that its Ergative-marked argument, as seen in (1), is an oblique causal complement.

$\begin{array}{lll}\text { (1) Алиди кицI } & \text { кьена. } \\ \text { Ali-di kic' } & \text { q'e-na. } \\ \text { Ali-ERG dog } & \text { kill-AOR } \\ \text { 'Ali killed the dog.' } & \end{array}$

Basically, all Lezgian clauses are claimed to be intransitive, so that the clause in (1) literally means 'The dog died through Ali' (see also [Mel'čuk, 2013]). This is thus a kind of "semantic ergativity" - the agent participant is treated in a special way at the semantic level. It can also be seen as a type of "deep" ergativity, because it is not only relevant at a "superficial" level of case-marking or person indexing. It represented a kind of "depth" of analysis that was prestigious at the time (after all, "deep structure" was still very much alive in the late 1970s, not only in Mel'čuk's framework), and that fascinated me in the 1980s.

But after studying Lezgian in some more depth (especially during my stay in Moscow in 1989-1990), I came to a different conclusion: In one of my first journal papers [Haspelmath, 1991], I set out to show that Mel'čuk's analysis was wrong: (1) was in fact a transitive clause.

But how could I tell? What is a "transitive clause" in general? How can a grammatical term be applied to different languages with different properties? Mel'čuk provides detailed discussions of the terms subject and ergative construction, and I learned a lot from his careful approach to what our grammatical terms mean (see also [Mel'čuk, 1982]). But he did not apply the same criteria to all languages, as we will see below. Thus, even if the facts and arguments of my (1991) paper were wrong, his claim would still be without a proper foundation. I will elaborate on this below in $\S 6$, but first I will review a number of robust findings about ergative and accusative alignment.

\section{Ergative and accusative alignment and what we can explain}

As all comparative linguists know, there are three widely attested alignment types, and two (mostly) unattested ones. This is true both for monotransitive clauses (with the arguments A and $\mathrm{P}$, which may contrast with the intransitive 
argument S) and for ditransitive clauses (with the object arguments $\mathrm{T}$ and $\mathrm{R}$, which may contrast with the monotransitive object P [Haspelmath, 2005]). Figure 1 shows the five logically possible types for monotransitive clauses (using a representation style that was first proposed by A.E. Kibrik, see 1979a, 1979b).

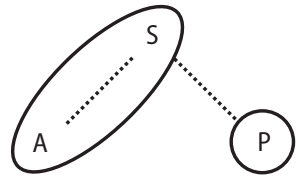

$a$

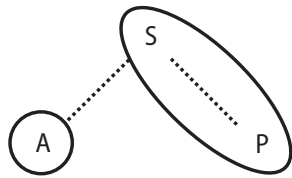

$b$

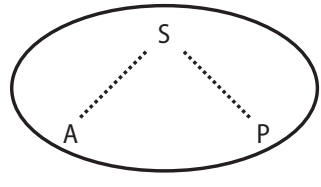

c

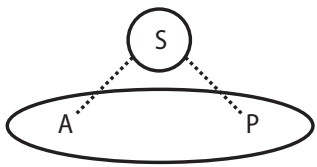

$d$

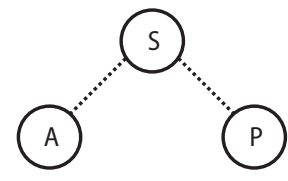

$e$

Fig. 1. Five alignment types of monotransitive $S, A$ and $P$ :

$a$ - accusative alignment; $b$ - ergative alignment; $c$ - neutral alignment;

$d$ - horizontal alignment; $e$ - tripartite alignment

The last two aligment types are virtually unattested [Comrie, 1978], which has a well-established functional explanation: tripartite alignment is uneconomical, and horizontal alignment does not make the right distinctions (see also [Haspelmath, 2015] for ditransitive alignment). Moreover, when we look at the flagging [Haspelmath, 2019] of the arguments in these constructions, we find an overwhelming tendency for the flagging to be asymmetric: For well-understood functional reasons, when there is flagging, it is the P-argument in accusative alignment, and the A-argument in ergative alignment that is flagged, while the nominative and absolutive arguments tend to be unflagged [Dixon, 1979; Haspelmath, 2005].

Now in addition to these well-known and well-understood facts, there are further generalizations about ergative marking that are less well known and not so widely understood as functionally motivated. These generalizations concern the role of referential prominence when the flagging is differential. For example, in Godoberi (a Nakh-Dagestanian language that was studied in a 1993 field trip led by A.E. Kibrik), the ergative flag - $d i$ is found only on full nominals and 3rd person demonstratives, but not on 1 st and 2 nd person independent pronouns, as seen in $(2 b)$. 
(2) Godoberi (Nakh-Dagestanian [Kibrik, 1996, p. 108])
a. imu-di
Sali
č'inni
father-ERG
Ali(ABS)
beat.PST
'Father beat Ali.'
b. $\min$
Sali
you
Ali(ABS)
č'inni
'You beat Ali.'
c. imu-di
$\min$
č'inni
father-ERG you
beat.PST
'Father beat you.'
(*min-di Cali č’inni)

This situation is sometimes called "differential subject marking" [de Hoop, de Swart, 2009], or more precisely "differential A marking". We use this term when there is a flagging split conditioned by the referential prominence properties of the A-argument. The generalization can be stated as in (3).

\section{(3) The DAM generalization}

Differential A-marking is found primarily with low-prominence A-arguments on the person scale, the animacy scale, and the focus scale, i.e.

- with 3rd person (vs. 1st/2nd person)

- with inanimates (vs. animates)

- focused (vs. topic) nominals

This pattern is a universal tendency, as a mirror image of differential object marking (e.g. [DeLancey, 1981; Schmidtke-Bode, Levshina, 2018]). Differential object marking is much better known, but it is not so well-known yet that an analogous pattern is also found in ditransitive constructions and in scenario splits, and can be generalized as follows:

(4) The role-reference association universal [Haspelmath, 2020b]

Deviations from usual associations of role rank and referential prominence tend to be coded by longer grammatical forms if the coding is differential.

For example, differential object marking tends to be found on definite or animate nominals, and analogously, differential (ditransitive) $\mathrm{R}$ marking tends to be found on indefinite nominals [Haspelmath, 2007]. This is because the $\mathrm{A}$ and $\mathrm{R}$ arguments are usually associated with high referential prominence, while the $\mathrm{P}$ and $\mathrm{T}$ arguments are usually associated with low referential prominence. I have claimed that this is a frequency effect [Haspelmath, 2020b]: "Usual association" means that these associations 
are the most frequent ones, and hence the most predictable - which means that it is efficient if they get less coding than the less predictable meanings. The generalization in (4) is just a special case of a much larger generalization, for which I have formulated the efficiency theory of asymmetric coding in grammar [Haspelmath, 2020a].

There is no space to elaborate on this here, but the general point is that quite a few initially puzzling aspects of the grammar of ergativity have good functional-adaptive explanations, and these have basically been known since the 1970s and 1980s (see also [Moravcsik, 1978]). It is against this background that we will now look at some ideas that were advanced by generative linguists in the meantime.

\section{4. "Depth of analysis" and measurement uniformity}

There is a widespread idea that good comparative grammar research must be based on "deep" or "detailed" analyses of particular languages, as opposed to the "superficial" or "coarse-grained" view of Greenbergian typology. This can be seen in quotations such as those in (5) (see also the discussion in [Croft, 2009, p. 147]).

(5) a. [Polinsky, Kluender, 2007, p. 275]

"[Typology's] allegiance to large samples and "superficial"

generalizations is simply one of the consequences of casting the net wide and looking for differences in a quick and easy way."

b. [Polinsky, 2011, p. 661]

"Such research allows us to uncover subtle distinctions and fine details of grammar that often remain unnoticed in a coarse-grained approach to language typology."

c. [Baker, 2015, p. 287]

"This testifies to the deep unity of human language, discernable underneath the surface diversity of case patterns."

d. [Bobaljik, 2015, p. 318]

"one of the hurdles to seeing more fruitful interaction between typological studies and formal generative approaches lies in the granularity of the questions being asked, and the degree to which we are ready to look beyond the surface descriptions, and to ask questions about patterns at a higher level of abstraction."

e. [Roberts, 2019, p. 12]:

"From the perspective of generative grammar, much typological analysis seems excessively surface-oriented." 
I would like to argue that this very widespread view is mistaken. The negligence of "depth of analysis" in broad comparative research is not a bug - it is a desirable feature.

It should go without saying that comparison of languages must be based on uniform "units of measurement". In other words, the concepts which we use to compare languages must be identified in the same way in all languages, like yardsticks. This is what I call "measurement uniformity", to be contrasted with "building block uniformity" below in $§ 8$. Linguists do not usually think of the concepts they use for comparison in terms of "measurement", but I think that this is a very useful metaphor. All empirical sciences involve comparison of research objects, and in many sciences this clearly involves measurement. Comparative linguistics can be seen in a very similar perspective (see [Round, Corbett, 2020]).

So let us go back to the issue of how to identify (or "measure") transitive clauses. A transitive clause is one with an A-argument and a P-argument, but how are A and P defined? Following Comrie (1978) and Lazard (2002), we can say that

- A is the agent argument of a physical-effect verb like 'kill' or 'break' (in the usual construction)

- $\mathrm{P}$ is the patient argument of such a verb

- $\mathrm{S}$ is the argument of a change-of-state verb like 'fall' or 'die' (see [Haspelmath, 2011])

We also want to talk about the arguments of other kinds of verbs, but these are usually coded in the same way as the physical-effect verbs and the typical change-of-state verbs, so they do not need to be considered separately in the definition.

Since all languages have physical-effect verbs and change-of-state verbs, and nominal arguments with particular coding properties (flagging and indexing), these comparative concepts can be applied to all languages uniformly, using the same criteria of measurement. (Alternatively, one might also use more fine-grained semantic roles, as in [Hartmann et al., 2014], where we compared alignment patterns on the basis of over a hundred microroles, which were semantically defined in the same way.) Since the universal claims of $\S 3$ are based on the well-defined notions of $\mathrm{A}, \mathrm{P}$ and $\mathrm{S}$, they are robust, and they can be readily tested, applying the same measurement criteria to all languages.

What is the alternative to this approach? One might try to compare languages in terms of a notion of "subject", but how can we recognize subjects uniformly across languages? Again and again, linguists have 
defined "subject" in such a way that different criteria are applied in different languages, e.g.

"...the SyntSubj [is] cross-linguistically universal. However, in a different sense, the SyntSubj is language-specific in so far as syntactic privileges are different in different languages: thus, in many Indo-European languages the main privilege of a clausal element is to impose agreement on the Main Verb, while in Malagasy it is to occupy the clause-final position" [Mel'čuk, 2013, p. x].

"We use the term 'subject' here as equivalent to what is termed 'privileged syntactic argument' (PSA) in Van Valin (2005) and elsewhere. A PSA is defined as the syntactic element that controls coding properties such as agreement and that is the pivotal element in complex constructions such as relativization, NP deletion, control, and so forth" [Riesberg et al., 2019, p. 524]

But this procedure is unlikely to pick out uniform phenomena across languages - if different subjects may be recognized by different criteria, how do we know that they are all "subjects" in the same sense? Maybe if "subject" were an innate category of a grammar blueprint, a genetically encoded building block for grammars, this method would be justifiable. I will briefly discuss this possibility below in $\S 8$, but first we will consider a recent influential approach to ergative case-marking.

\section{Mark Baker's theory of "dependent case"}

We saw in (5c) that Mark Baker is one of those generative grammarians who wants to go "below the surface diversity" of languages, so let us examine his recent theory of ergative case-marking. Baker (2015) presents a theory of "dependent case", in which he says that grammatical case-marking patterns in the world's languages are usually determined by dependent-case rules which roughly look as in (6) (the presentation here is greatly simplified).

(6) a. High case in the clause is ergative.

b. Low case in the clause is accusative.

c. High case in VP is dative.

e. High case in NP is genitive.

f. Unmarked case is nominative-absolutive.

So in a Lezgian clause like (7), the agent nominal Ali gets ergative case because it is "high" in the clause, the nominal $z a$ - 'I' gets dative case because it has a "high" position in the VP, and the "low" nominal ktab 'book' gets unmarked (absolutive) case because none of the other rules apply to it. 
(7)

$\begin{array}{lrrll}\text { Cls: NP } & & & \rightarrow & \text { ERG } \\ \text { VP: } & \text { NP } & \rightarrow & \text { DAT } \\ \text { VP: } & & \text { NP } & \rightarrow & \text { unmarked = ABS } \\ \text { Алиди } & \text { заз } & \text { ктаб } & \text { вугана. } \\ \text { Ali-di } & \text { za-z } & \text { ktab } & \text { wuga-na. } \\ \text { Ali-ERG } & \text { I-DAT } & \text { book } & \text { give-AOR } \\ \text { 'Ali gave } & \text { me a book.' [Mel'čuk, 1988] }\end{array}$

In my review of Baker's book [Haspelmath, 2018b], I noted that this approach seems better than many other generative proposals in that it treats ergative marking in parallel to accusative marking and thus catches up to some extent with the insights of Comrie (1978), Moravcsik (1978) and Dixon (1979) that were mostly ignored by earlier generative researchers. ${ }^{2}$

But elsewhere, he appeals to a movement operation in order to explain some case-marking effects, making use of a popular generative device that has no analogue in other approaches. For example, Sakha (a Turkic language) has differential object marking on definite nominals [Baker, 2015, p. 125-126], and the lack of object marking (as in $8 \mathrm{~b}$ ) is associated with directly preverbal order.

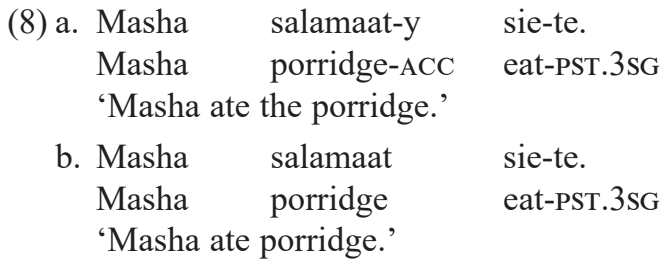

This can be seen when there is a manner adverb like türgennik 'quickly': This can occur between the verb and the object only when the object is definite and bears accusative case, as in (9a) (but not in 9b). (The examples in (8) and (9) come from [Baker, 2015, p. 125-126].)

$\begin{array}{llll}\text { (9) a. Masha salamaat-y türgennik } & \text { sie-te. } \\ \text { Masha porridge-ACC quickly } & \text { eat-PST.3sG } \\ \text { 'Masha ate the porridge quickly.' } & \end{array}$

${ }^{2}$ Comrie and Dixon are well-known for having introduced the role-types S, A and P to describe accusative and ergative patterns. Baker uses "high" and "low" positions instead (defined in terms of c-command), but de facto, there does not seem to be much of a difference, because Baker determines these "positions" in semantic terms, not through any constituency tests (cf. his clear statement: "We should not expect to find many differences between c-command and a notion like thematic prominence, since the two notions are closely related" [Baker, 2015, p. 81]). 

(9) b. Masha
türgennik
salamaat
sie-te.
Masha quickly
porridge
eat-PST.3sG
'Masha ate porridge quickly.' (*salamaat türgennik siete)

Baker (2015, p. 126) appeals to a complex movement operation and an abstract notion of "spell out domain" in order to explain the accusative marking in such cases. In this sense his description is not "surface-oriented", but "deep".

But while his complicated story explains the Sakha object marking facts, he misses the generalization that differential object marking is found on definite objects also when there is no word order alternation, as in Hebrew and Romanian. By contrast, the role-reference association universal of (4) above makes no reference to word order, so it generalizes to these languages, and its explanation in terms of efficient coding does, too.

In addition to being insufficiently general, Baker's theory in terms of "deep analyses" has the serious problem that it is not objectively testable. There is no unique way of determining a "deep analysis", so Baker spends many pages on trying to persuade his readers of the correctness of his choices. His claims do not apply directly to observable facts of languages, but to particular analyses, where different considerations play a role for different languages. This means that we have to rely on the analysis being correct, but the analysis in turn relies on the general theory, so there is no way to make the process objective.

A striking example of this problem is Baker's (2015, p. 222) discussion of the case of predicate nominals, which brings us back to ergativity and Lezgian. Baker notes that his theory would lead us to expect ergative case on the subject of a nonverbal-predicate clause such as (10), because the subject is "higher" in terms of the structure assumed by Baker. However, what we actually find in Lezgian is an Absolutive subject; here Baker cites an example from my (1993) grammar of Lezgian (although an example from any other language with ergative flagging would have done as well).

(10) NP

$\begin{array}{lllll}\text { Зи } & \text { буба } & \text { Йоханес } & \text { кP } \\ \mathrm{Zi} & \text { buba } & \text { Joxanes } & \text { kešiš } & \text { я. } \\ \text { my } & \text { father(ABs) } & \text { Johannes(ABS) } & \text { priest(ABs) } & \text { COP } \\ \text { 'My father Johannes is a minister.' (from [Haspelmath, } & \text { 1993, p. 311]) }\end{array}$

So why doesn't the subject bear Ergative case in Lezgian? Baker proposes that there is an extra projection "EP" between the subject and the predicate, so that the relationship between the two nominals is not as local as it would need to be for ergative case to be assigned to the subject. We thus have the hierarchy of projections in (11). 
(11) NP

EP

NP

The "E" slot (which projects an EP that prevents case assignment) is said to be generally empty, but may be attested in Tamil (which has a suffix -aa following the predicate nominal).

Thus, Baker makes the following methodological move:

(12) Hypothesize that an underlying element exists, and look for phenomena that might match this phenomenon.

If there is something to be found (whatever it may be), this is taken as confirmation.

This method was called "diagnostic-fishing" in an earlier paper ([Haspelmath, 2018a, p. 102]; [Croft, 2009] called it "methodological opportunism"). It is not a rigorous method, because there is no clear prediction that could be confirmed or disconfirmed. If nothing were found that might match the hypothesized "E" element, the hypothesis could still stand. Moreover, confirmation bias is one of the best-known problems in all domains of knowledge acquisition, and if we only look for confirming cases, we are likely to be led into wrong directions. Instead, we need an objective method of measuring and counting effects, where it is clear what kinds of phenomena would count as disconfirming cases. Thus, even though Baker's analysis may look "deep" because of its complexity, it is actually not very reliable.

Another example of diagnostic-fishing is Baker's treatment of oblique nominals. He observes that languages generally do not have ergative case on the subject when the second argument is oblique-marked, as seen in the following examples of languages with ergative flagging [Baker, 2015, p. 185-186].

(13) a. Ingush

$\begin{array}{llll}\text { Ahwmad } & \text { suona } & \text { ulu } & \text { laatt. } \\ \text { Ahmed } & \text { I.DAT } & \text { next.to } & \text { stand.PRS }\end{array}$

'Ahmed is standing next to me.' [Nichols, 2011, p. 401]

b. Shipibo

$\begin{array}{lll}\text { Jose(-*kan) } & \text { ochiti-ki } & \text { raket-ai. } \\ \text { Jose(-ERG) } & \text { dog-DAT } & \text { fear-IMPF } \\ \text { 'José fears the dog.' (from } & \text { Baker's own primary data) }\end{array}$

Baker's theory predicts that Ahwmad in the Ingush example should be in the unmarked (absolutive) case in (13a), because the other argument is an adpositional phrase (a PP) and thus not sufficiently local. But Jose 
in the Shipibo example should carry ergative case, because the object nominal is not a PP, but an NP whose noun carries dative case. To solve this problem, Baker hypothesizes that such dative nominals are in fact PPs in Shipibo, with an empty adposition that assigns dative case. This makes the analysis more complicated, and Baker cites no independent evidence for it, but it allows him to save the general theory.

Elsewhere in his book, he posits not only empty adpositions (in PP) that assign case, but also surface adpositions that are really case forms (in NP), and surface case forms that are really adpositions (in PP) $(2015$, p. 2,9$) .{ }^{3}$ For such cases, he says that "the theory will have to decide (p. 13)" - in other words, the theory is not motivated here. Baker is aware that he should be able to provide such evidence, and he says that one must "hope that one can find some fine-grained syntactic properties which distinguish the two kinds [...]: a process of clefting, perhaps, or quantifier floating - the sorts of syntactic phenomena known to apply to NPs but not to PPs in some languages". The theory is thus not so much built on actual in-depth analyses, but on the hope that after looking at more data, one will eventually find converging evidence that confirms the theory.

Many linguists have been skeptical of such abstract analyses that posit seemingly unmotivated zeroes, but what is the problem with abstract elements like zeroes? If "depth of analysis" is a virtue, then deep, abstract analyses should always give us greater insight. But even Baker is not always in favour of very abstract analyses. In the introductory chapter, he mentions the possibility that ALL languages have both accusative and ergative case at the syntactic level, and that they differ in that some languages spell out some of the case features by zero. Baker comments:

"We could contemplate taking a more radical view, which would claim that all languages are really tripartite languages in their syntactic case marking... Some strict minimalist theorists might find this view attractive. However, I believe that this universalist view goes too far. Rather, I claim that languages are parameterized..." [Baker, 2015, p. 25-26]

But how do we know that this degree of abstractness "goes too far", whereas the level of abstractness that Baker chooses is the right one? It seems

${ }^{3}$ Zero adpositions that assign ergative case are also posited by Polinsky (2016) in her theory of two types of ergativity, but for rather different reasons than Baker. Polinsky wants to explain that some languages have extraction restrictions on ergative nominals, and she suggests that this is due to the PP status of ergative nominals in these languages. She devotes an entire chapter of her book (2016, p. 56-71) to discussing diagnostics of PPs that distinguish them from NPs, but she admits that "the paucity of strong operational diagnostics for PPs signals the need for more work in this area" (2016, p. 56). Thus, Polinsky has the same problems as Baker, and her proposal remains an intriguing speculation. 
that the choices are subjective and depend on the researcher's hunches, not any systematic research methods.

The alternative that I propose is to compare language structures not at some "deep" or abstract level of analysis that cannot be established objectively, but at the level of the community norms. In other words, we do not need a description that corresponds to the mental grammars of the speakers (let alone a description that is framed in the innate building blocks of a universal grammar blueprint). Thus, any pedagogical grammar should be sufficient for comparative purposes, and in fact, typological databases as exemplified by the World atlas of language structures do sometimes make use of information from pedagogical grammars. One may call this approach "shallow" (and thus frame it negatively), but I would call it "rigorous", because the community norms are not in doubt in the same way as the hypothesized mental grammars. Thus, this approach allows objective comparison in a way that the grammar-blueprint approach does not allow. ${ }^{4}$

\section{Mel'čuk and Lezgian again}

Let us now get back to Mel'čuk and his discussion of ergativity in Lezgian and the notion of "subject". He provides the following definition of "subject" (1988, p. 163):

(14) "A grammatical subject (GS) in $\mathbf{L}$ is either a basic GS or any other nominal that is most similar to the basic GS from the viewpoint of relevant syntactic properties $\left\{\mathrm{P}_{\mathrm{i}}\right\}$."

In addition, he observes: ${ }^{5}$

"The syntactically privileged status of NPs is language-specific. Thus a syntactic property relevant in one language may turn out nonexistent or immaterial in another. For example, controlling the agreement of the main verb is a mark of privileged status in Russian or Italian, while it does not appear at all in Dyirbal, Lezgian or Japanese...”

He walks through a number of subject criteria and argues that the agent nominal in the presumed Lezgian "ergative construction" (as seen in (1), repeated here) lacks these subject properties (see [Haspelmath, 1991] for detailed discussion; in that old paper, I did not take issue with Mel'čuk's definitions and methodology, but with some of the Lezgian facts that he presented).

${ }^{4}$ Of course, the community norms are often variable, and thus present an independent challenge for description and cross-linguistic comparison. But the mental-grammar approach has these problems in addition to the problem of subjectiveness of choices.

${ }^{5}$ Essentially the same conception of the notion of subject is discussed in more detail in [Mel'čuk, 2013]. 


\section{(1) Алиди кицІ кьена. \\ Ali-di kic' q'e-na. \\ Ali-ERG dog kill-AOR \\ 'Ali killed the dog.'}

Although Mel'čuk is not a Chomskyan and is not committed to the innateness of the building blocks of grammar, he still proposes that different languages can make use of different properties or criteria for determining which argument is the subject of a clause. In this regard, he is not different from authors like Baker, and his method is thus not objective. ${ }^{6}$

This can be seen in a footnote that was added to the second version of his paper (1988, p. 244), where Mel'čuk admits that A. E. Kibrik (1979-1980) has noted some phenomena that seem to contradict his analysis, because the ergative subject (and also the dative experiencer) seems to have the same privileges of occurrence in 'want' complements as the absolutive subject. In (15a-c), we see that not only the absolutive and ergative argument can be omitted in control constructions with 'want', but also the dative experiencer argument of 'see'. By contrast, the dative stimulus argument of 'look at' cannot be be omitted in control constructions, as can be seen in (15d), where a different construction (using the converbal form of the verb rather than the infinitive) is used. (See also [Haspelmath, 1993, p. 295-298].)

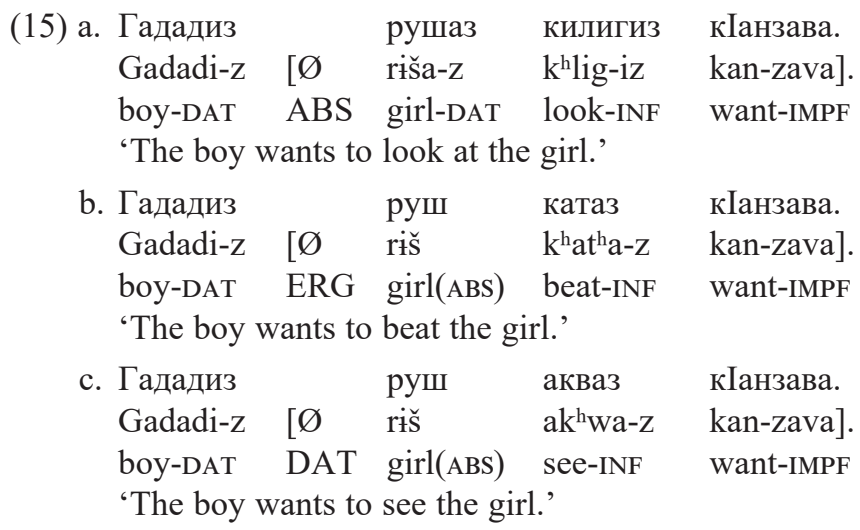

${ }^{6}$ Dmitrij Zelenskij (p.c.) points out to me, quite rightly, that generative syntacticians typically appeal to c-command relations when discussing syntactic-role phenomena like subjects and objects. But c-command is not directly observable, and tree structures are in fact often established in a circular way (by citing binding phenomena rather than standard constituency tests, on the assumption that binding is always governed by c-command, even though this is far from established). Thus, this is not any more objective than what I describe in $\S 6$. As Adam Tallman (p.c.) points out, Baker does not even provide any evidence for the claimed c-command relationships for most of the languages he discusses. 


\begin{tabular}{|c|c|c|c|c|}
\hline (15) d. Гададиз & руш & вичиз & килигна & кІанзава. \\
\hline Gagadi-z & [rìs & üčch $\ddot{\mathrm{u}}-\mathrm{z}$ & $k^{\text {hlig-na }}$ & kan-zava]. \\
\hline boy-DAT & $\operatorname{girl}(\mathrm{ABS})$ & self-DAT & look-CVB & want-IMPF \\
\hline
\end{tabular}

However, these facts do not lead Mel'čuk to change his mind, and he concludes:

"I would still say that in Lezgian, the [absolutive nominal] of all verbs is the grammatical subject, that is, I would stand my ground anyway. The reason is that, to me, in Lezgian the property of PRO-control is motivated semantically... regardless of its actual surface-syntactic role... I consider the property "being a PRO-controller" as less weighty or less relevant than the previously considered subjecthood properties..." [Mel'čuk, 1988, p. 247]

So clearly, this represents an arbitrary choice of criteria. Unfortunately, it is not so uncommon in linguistics that the choice of criteria is made on an unprincipled basis, though it is rarely admitted so clearly. (Another example of this sort of honesty is Börjars (1998, p. 44), in a discussion of clitic vs. affix status: "The behaviour of elements is often not totally consistent. This means that in order to arrive at the conclusion that an element is either a clitic or an affix, certain criteria must be assumed to be less crucial.")

So like Baker's work on case, Mel'čuk's work on "subject" and "ergative" illustrates the fact that we need to use the same criteria (the same yardsticks for measurement) in all languages if we want objective cross-linguistic comparisons. The definitions of $\mathrm{A}, \mathrm{P}$ and $\mathrm{S}$ given in $\S 4$ can be applied to all languages in the same way. By these definitions, it is clear that Lezgian clauses like (1) have an A and a P and are thus transitive.

\section{What "depth of analysis" is good for}

I conclude from the discussion of the last two sections that that the muchpraised "detailed" and "deep" analyses of generative grammar may have limited value for comparative purposes. They presuppose that we already know the innate building blocks of universal grammar, but since we do not have any certainty about them (and in fact do not even have any concrete proposals, unlike the concrete proposals for innate building blocks of segmental phonology in the tradition of [Chomsky, Halle, 1968], i.e. the features), we cannot rely on them.

Of course, "detailed" study is good, and in fact necessary - we want to know everything about all languages. Not only all the words, but also all the constructions and all their interactions need to be studied. Grammatical descriptions should be comprehensive and complete, and as we now know, 
they should consist of many volumes to capture all the rules that speakers know, just as complete dictionaries sometimes consist of many volumes.

But "deep" analysis is not necessarily good, because it is often unclear whether our "deep" generalizations are actually true. In [Haspelmath, 1991, 1993], I ended up saying that there is some evidence for a Subject category in Lezgian, because this allows us to generalize over intransitive Absolutive, transitive Ergative, and experiencer Dative arguments, which behave alike in 'want' complements clauses (see (15a-d) above). But the evidence for this is hardly compelling. There are only two rules of Lezgian that would have to be stated separately if there were no Subject category, so we would have six rules instead of two rules and one category. But all languages have thousands of syntactic rules anyway, so there are no strong reasons to think that Lezgian speakers must make this generalization and thus posit a Subject category in their mental grammars. Linguists do not make such calculations often, but in fact, our evidence that speakers make the same generalizations as linguists is often extremely limited.

Moreover, so-called "deep analysis" is often not so much motivated by the goal of understanding the structures of a particular language in very general terms, but rather by the attempt to fit the description of a language into a mould that is hypothesized to be an innate blueprint that universally applies to all languages. This blueprint approach has not yielded very clear results so far, so it is not something that studies of individual language would necessarily profit from.

\section{Measurement uniformity and building-block uniformity}

So to repeat the main point that I want to make in this paper: Instead of "depth of analysis", comparative research is best based on objectively defined comparative concepts [Haspelmath, 2010]. In (16a-e), I provide some definitions of comparatively defined general categories that were used in the generalizations and explanations in $\S 3$ above.

\section{(16) a. transitive construction:}

$=$ a minimal-clause construction with an A-argument and a P-argument

[Haspelmath, 2011]

b. A-argument and P-argument:

= the 'killer/breaker' argument of the verbs 'kill/break', and arguments that have the same kind of argument coding

c. argument coding:

= flagging and indexing (cf. [Haspelmath, 2019]) 


\section{(16) d. ergative flag:}

$=\mathrm{a}$ flag that can be used for the $\mathrm{A}$ but not for the $\mathrm{P}$ or the $\mathrm{S}$

\section{e. S-argument:}

$=$ the 'faller/dieer' argument of the verbs 'fall/die' and arguments that have the same kind of argument coding

On the basis of the notion of an "ergative flag", one can formulate and test universals about differential ergative marking, as illustrated by Godoberi ((2a-c) above). As we saw, these universals have a good functional explanation in terms of efficient grammatical coding.

The ergative concept in (16d) refers to a kind of concrete audible grammatical form, not to a kind of abstract case feature. This allows us to apply the concept also in languages where the syntax is more complicated than in Lezgian. Baker (2015) operates in terms of invisible abstract case features, which are often (but need not be) spelled out on the "surface". For example, he assumes zero spellout for the classical Australian split-ergative languages, such as Diyari [Austin, 1981], whose case suffixes are shown in (17).

$\begin{array}{clll}\text { (17) } & 1 \mathrm{st} / 2 \mathrm{nd} & \text { other pronouns } & \text { full nouns } \\ \mathrm{A} & \varnothing & -l i & -l i(\mathrm{ERG}) \\ \mathrm{P} & -\underline{n} a & -\underline{n} a(\mathrm{ACC}) & -\varnothing(\mathrm{ABS}) \\ \mathrm{S} & \varnothing & \varnothing & -\varnothing(\mathrm{ABS})\end{array}$

Baker regards such languages as having "tripartite case", with widespread zero-realization. He thus misses the generalization that these languages conform to the high-level generalization about differential flagging that we saw earlier:

\section{(4) The role-reference association universal}

Deviations from usual associations of role rank and referential prominence tend to be coded by longer grammatical forms if the coding is differential. [Haspelmath, 2020b]

An ergative flag is not used with prominent (locuphoric) A-arguments, and an accusative flag is not used with non-prominent (full nominal) P-arguments, regardless of the syntactic features. And Arkadiev (2017) observes that when a language has two different ergative markers, there is a (slight) preference for the longer ergative marker to be used with less prominent referents. These effects of formal coding are predicted by efficiency of coding, but not by Baker's abstract features.

But of course, Baker is not alone in adopting an approach that appeals to abstract innate categories. Like all generative grammarians, Baker assumes a universal grammar blueprint that gives us building-block uniformity: All 
languages are basically made from the same innate elements. These building blocks are not only the stuff of language-particular analyses, but also the basis of cross-linguistic comparison.

This is a possible methodological choice, but Baker and most other generative grammarians provide no arguments - building-block uniformity is often simply assumed, as if no alternative existed. ${ }^{7}$ But there is a clear alternative, which is better at least for the phenomena mentioned in this paper: Descriptive categories are used for language-particular generalizations, and comparative concepts are used as yardsticks for measurement uniformity [Haspelmath, 2010; 2018].

If one adopts an approach to comparison that does not rely on universal building blocks, this also means that it makes no sense to distinguish between "typology" and "theory", as is done all too often. For example, E. Lyutikova \& A. Zimmerling say:

"The parameterization of linguistic diversity is an area that requires the collaboration of language typology and grammatical theory. Contemporary language typology is primarily an inductive science..." [Lyutikova, Zimmerling, 2018, p. 13]

On the alternative view, both comparative research and language particular research is theoretical (contrasting with applied linguistics, such as language pedagogy and translation studies). But there are two different types of theories:

Language-particular research (p-linguistics) creates language-particular theories, whereas comparative research creates comparative and general theories (g-linguistics). The difference between generative (Baker-style) comparative grammar and Greenberg-style comparative grammar is that Baker-style comparison relies on innate building blocks, while Greenbergstyle comparison does not. Comparative linguistics is partly top-down and partly bottom-up, like all sciences. Maybe "inductive" here means that Greenberg-style comparative linguistics is less prone to making highly speculative proposals, but eventually, every theory needs to be tested, and every observation must find its place in some theory.

While I have been very critical of the idea of innate building blocks of a grammar blueprint, such innate categories with relevance to cognition are certainly possible. It is an established result that there are five basic innate tastes (sweet, sour, bitter, salty, and umami), and there is a widely discussed serious hypothesis that there are five basic innate emotions (e.g. [Barrett, 2006]). Thus, there might be five basic innate parts of speech, or five basic

${ }^{7}$ Cf. Polinsky's honest statement: "the building blocks are assumed, without much empirical evidence, to be the same across all languages" [Polinsky, 2011, p. 652]. 
innate tense-aspect categories. This does not seem likely to most linguists, and in recent years, it has been suggested that "Darwin's Problem" rules out this possibility because such categories could hardly have evolved during the short time that separates humans from apes (see [Berwick, Chomsky, 2016]). But it is certainly a possibility that should be taken into account.

How do we find out which approach is on the right track? The answer is simple: We look which approach finds the better (more stable) theories which fit the world's linguistic diversity better - though we should probably invest less in the building-block uniformity approach, because of its inherent unlikeliness. Baker (2015) has not compared his approach with those of Comrie (1978), Moravcsik (1978) and Dixon (1979), but simply dismissed these approaches as non-generative. But the old theories actually fare better [Haspelmath, 2018b, 2020b]. ${ }^{8}$

\section{Conclusion}

The most general point that I want to make in this paper is that the primary contrast in comparative linguistics is not between "typology" (Greenberg-style) and "parameteric theory" (Baker-style), but between two methodological orientations: measurement uniformity and building-block uniformity.

In chemistry, the building-block uniformity approach has worked well, as is shown by the spectacular success of Mendeleyev's Periodic Table of Elements. It is conceivable that it will work in linguistics as well I call it the Mendeleyevian Vision (which is explained well in some detail by [Baker, 2001]).

But measurement uniformity, making use of clearly defined comparative concepts, is the more tractable approach, which allows us to engage in systematic and quantitative language comparison even before we have discovered the innate categories of our presumed grammar blueprint. This approach is based on the facts of languages independently of "deep" or highly abstract analyses, so its implementation does not have to wait for success in finding the innate building blocks of all grammars. We can identify universals of grammar like those in $\S 3$ and contemplate possible explanations for them without being certain about language-particular analyses and without knowing much about the innate predispositions for language.

\footnotetext{
${ }^{8}$ To be fair, I should perhaps note that Baker sets himself two goals at the same time: that of explaining universals in the world's languages, and that of using the same building blocks to describe the languages in an elegant fashion (cf. his 2018 reply to my 2018 review, p. 496). I do not think that this is the right strategy, as language-particular phenomena are often no more than historical accidents.
} 


\section{References}

Arkadiev, 2017 - Arkadiev P. Multiple ergatives. Studies in Language. 2017. No. 41 (3). Pp. 717-780. DOI: 10.1075/s1.41.3.06ark.

Austin, 1981 - Austin P.K. A grammar of Diyari, South Australia. Cambridge, 1981.

Baker, 2001 - Baker M.C. The atoms of language. New York, 2001.

Baker, 2015 - Baker M.C. Case: Its principles and parameters. Cambridge, 2015.

Baker, 2018 - Baker M.C. Reply to the reviews of "Case: Its principles and parameters." Studies in Language. 2018. No. 42 (2). Pp. 487-503.

Barrett, 2006 - Barrett L.F. Are emotions natural kinds? Perspectives on Psychological Science. 2006. No. 1 (1). Pp. 28-58. DOI: 10.1111/j.17456916.2006.00003.x.

Berwick, Chomsky, 2016 - Berwick R.C., Chomsky N. Why only us: Language and evolution. Cambridge, MA, 2016.

Bobabljik, 2015 - Bobabljik J. Distributed Morphology: An interview with Jonathan Bobaljik. Revista Virtual de Estudos da Linguagem (ReVEL). 2015. No. 13. Pp. 314-321.

Börjars, 1998 - Börjars K. Feature distribution in Swedish noun phrases. Oxford, 1998.

Chomsky, Halle, 1968 - Chomsky N., Halle M. The sound pattern of English. New York, 1968.

Comrie, 1978 - Comrie B. Ergativity. Syntactic typology: Studies in the phenomenology of language. W.P. Lehmann (eds.). Austin, 1978. Pp. 329-394.

Croft, 2009 - Croft W. Methods for finding universals in syntax. Universals of language today. S. Scalise, E. Magni, A. Bisetto (eds.). Dordrecht, 2009. Pp. 145-164.

de Hoop, de Swart, 2009 - Differential subject marking (Studies in Natural Language and Linguistic Theory 72). H. de Hoop, P. de Swart (eds.). Dordrecht, 2009.

DeLancey, 1981 - DeLancey S. An interpretation of split ergativity and related patterns. Language. 1981. No. 57. Pp. 626-657.

Dixon, 1979 - Dixon R.M.W. Ergativity. Language. 1979. No. 55. Pp. 59-138.

Hartmann et al., 2014 - Hartmann I., Haspelmath M., Cysouw M. Identifying semantic role clusters and alignment types via microrole coexpression tendencies. Studies in Language. 2014. No. 38 (3). Pp. 463-484.

Haspelmath, 1991 - Haspelmath M. 1991. On the question of deep ergativity: The evidence from Lezgian. Papiere zur Linguistik. 1991. No. 44/45 (1-2). Pp. 5-27. DOI: $10.5281 /$ zenodo.225289.

Haspelmath, 1993 - Haspelmath M. A grammar of Lezgian. (Mouton Grammar Library 9.). Berlin, 1993.

Haspelmath, 2005 - Haspelmath M. Argument marking in ditransitive alignment types. Linguistic Discovery. 2005. No. 3 (1). Pp. 1-21.

Haspelmath, 2007 - Haspelmath M. Ditransitive alignment splits and inverse alignment. Functions of Language. 2007. No. 14 (1). Pp. 79-102.

Haspelmath, 2010 - Haspelmath M. Comparative concepts and descriptive categories in crosslinguistic studies. Language. 2010. No. 86 (3). Pp. 663-687. DOI: $10.1353 /$ lan.2010.0021.

Haspelmath, 2011 - Haspelmath M. On S, A, P, T, and R as comparative concepts for alignment typology. Linguistic Typology. 2011. No. 15 (3). Pp. 535-567. 
Haspelmath, 2015 - Haspelmath M. Ditransitive constructions. Annual Review of Linguistics. 2015. No. 1. Pp. 19-41. DOI: 10.1146/annurev-linguist-030514125204.

Haspelmath, 2018a - Haspelmath M. How comparative concepts and descriptive linguistic categories are different. Aspects of linguistic variation: Studies in honor of Johan van der Auwera. D. Van Olmen, T. Mortelmans, F. Brisard (eds.). Berlin, 2018. Pp. 83-113. DOI: http://doi.org/10.5281/zenodo.570000.

Haspelmath, 2018b - Haspelmath M. Review of "Baker, Mark. 2015. Case. Cambridge: Cambridge University Press." Studies in Language. 2018. No. 42 (2). Pp. 474-486.

Haspelmath, 2019 - Haspelmath M. Indexing and flagging, and head and dependent marking. Te Reo. 2019. No. 62 (1). Pp. 93-115. DOI: 10.17617/2.3168042.

Haspelmath, 2020a - Haspelmath M. Explaining grammatical coding asymmetries: Form-frequency correspondences and predictability. 2020. To appear. URL: https:// ling.auf.net/lingbuzz/004531

Haspelmath, 2020b - Haspelmath M. Role-reference associations and the explanation of argument coding splits. Linguistics. 2020. To appear. URL: https:// ling.auf.net/lingbuzz/004047

Kibrik, 1979a - Kibrik A.E. Canonical ergativity and Daghestan languages. Ergativity: Towards a theory of grammatical relations. F. Plank (ed.). New York, 1979. Pp. 61-78.

Kibrik, 1979b - Kibrik A.E. The subject and problem of the universal language model. Izvestija AN SSSR: Serija literatury i jazyka. 1979. No. 38 (4). Pp. 309-317. (In Russ.)

Kibrik, 1996 - Godoberi. Kibrik A. (ed.). München, 1996.

Lazard, 2002 - Lazard G. Transitivity revisited as an example of a more strict approach in typological research. Folia Linguistica. 2002. No. 36 (3-4). Pp. 141-190.

Lyutikova, Zimmerling, 2018 - Lyutikova E.A., Zimmerling A.V. Typology of morphosyntactic parameters: Why are languages so predictable? Tipologija morfosintaksičeskix parametrov. 2018. No. 1 (1). Pp. 11-31. (In Russ.)

Mel'čuk, 1982 - Mel'čuk I.A. Towards a language of linguistics: A system of formal notions for theoretical morphology. Munich, 1982.

Mel'čuk, 2013 - Mel'čuk I.A. Syntactic subject, once again. Proceedings of the 6th International Conference on Meaning-Text Theory, Prague, August 30-31, 2013. V. Apresjan, B. Iomdin, E. Ageeva (eds.). Prague, 2013. Pp. iii-xxxiii.

Mel'čuk, 1981 - Mel'čuk I.A. Grammatical subject and the problem of the ergative construction in Lezgian. Studies in the Languages of the USSR. B. Comrie (ed.). Carbondale \& Edmonton, 1981. Pp. 229-276.

Mel'čuk, 1988 - Mel'čuk I.A. Dependency syntax: Theory and practice. Albany, 1988.

Moravcsik, 1978 - Moravcsik E.A. On the case marking of objects. Universals of human language. J.H. Greenberg (ed.). Vol. 4: Syntax. Pp. 249-289. Stanford, 1978.

Nichols, 2011 - Nichols J. Ingush grammar. (University of California Publications in Linguistics, 141). Berkeley, 2011.

Polinsky, Kluender, 2007 - Polinsky M., Kluender R. Linguistic typology and theory construction: Common challenges ahead. Linguistic Typology. 2007. No. 11 (1). Pp. 273-283. DOI: 10.1515/LINGTY.2007.022. 
Polinsky, 2011 - Polinsky M. Linguistic typology and formal grammar. The $O x$ ford handbook of linguistic typology. Jae Jung Song (ed.). Oxford, 2011.

Polinsky, 2016 - Polinsky M. Deconstructing ergativity: Two types of ergative languages and their features. New York, 2016.

Riesberg et al., 2019 - Riesberg S., Malcher K., Himmelmann N.P. How universal is agent-first? Evidence from symmetrical voice languages. Language. 2019. No. 95 (3). Pp. 523-561. DOI: 10.1353/lan.2019.0055.

Roberts, 2019 - Roberts I. Parameter hierarchies and universal grammar. Oxford, 2019.

Round, Corbett, 2019 - Round E., Corbett G.G. Comparability and measurement in typological science: The bright future for linguistics. 2019. To appear.

Schmidtke-Bode, Levshina, 2018 - Schmidtke-Bode K., Levshina N. Assessing scale effects on differential case marking: Methodological, conceptual and theoretical issues in the quest for a universal. Diachrony of differential argument marking. I.A. Seržant, A. Witzlack-Makarevich (eds.) (Studies in Diversity Linguistics 19). Berlin, 2018. Pp. 463-489.

Van Valin, 2005 - Van Valin R.D., Jr. Exploring the syntax-semantics interface. Cambridge, 2005.

Статья поступила в редакцию 16.10.2019

The article was received on 16.10.2019

\section{O6 авторе / About the author}

Martin Haspelmath - Dr. Phil. Hab.; Senior scientist at the Department of Linguistic and Cultural Evolution, Max Planck Institute for the Science of Human History, Jena, Germany; Adjunct Professor at the Institute of English Studies, Leipzig University, Germany

Хаспельмат Мартин - доктор филологических наук; старший научный сотрудник отдела языковой и культурной эволюции, Институт истории человечества Общества Макса Планка, Йена, Германия; адъюнкт-профессор кафедры английской филологии, Лейпцигский университет, Германия

ORCID: orcid.org/0000-0003-2100-8493

E-mail: haspelmath@gmail.com 